\title{
Phase Formation and Thermal Stability of Reactively Sputtered $\mathrm{YTaO}_{4}-\mathrm{ZrO}_{2}$ Coatings
}

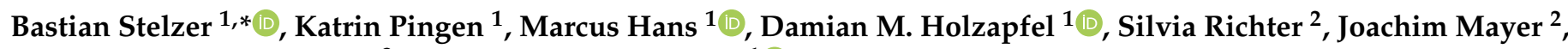 \\ Konda Gokuldoss Pradeep ${ }^{3}$ and Jochen M. Schneider ${ }^{1}$ (I)
}

1 Materials Chemistry, RWTH Aachen University, 52074 Aachen, Germany; katrin.pingen@rwth-aachen.de (K.P.); hans@mch.rwth-aachen.de (M.H.); holzapfel@mch.rwth-aachen.de (D.M.H.); schneider@mch.rwth-aachen.de (J.M.S.)

2 Central Facility for Electron Microscopy, RWTH Aachen University, 52074 Aachen, Germany; richter@gfe.rwth-aachen.de (S.R.); mayer@gfe.rwth-aachen.de (J.M.)

3 Department of Metallurgical and Materials Engineering, Indian Institute of Technology Madras, Chennai 600036, India; kgprad@iitm.ac.in

* Correspondence: stelzer@mch.rwth-aachen.de

check for updates

Citation: Stelzer, B.; Pingen, K.; Hans, M.; Holzapfel, D.M.; Richter, S.; Mayer, J.; Pradeep, K.G.; Schneider, J.M. Phase Formation and Thermal Stability of Reactively Sputtered $\mathrm{YTaO}_{4}-\mathrm{ZrO}_{2}$ Coatings. Materials 2021, 14, 692. https:// doi.org/10.3390/ma14030692

Academic Editor: Frank Czerwinski Received: 30 December 2020

Accepted: 27 January 2021

Published: 2 February 2021

Publisher's Note: MDPI stays neutral with regard to jurisdictional claims in published maps and institutional affiliations.

Copyright: (c) 2021 by the authors. Licensee MDPI, Basel, Switzerland. This article is an open access article distributed under the terms and conditions of the Creative Commons Attribution (CC BY) license (https:// creativecommons.org/licenses/by/ $4.0 /)$.

\begin{abstract}
Y}_{(1-\mathrm{x}) / 2} \mathrm{Ta}_{(1-\mathrm{x}) / 2} \mathrm{Zr}_{\mathrm{x}} \mathrm{O}_{2}$ coatings with 0 to $44 \mathrm{~mol} \% \mathrm{ZrO}_{2}$ were synthesized by sputtering. Phase-pure $M^{\prime}-\mathrm{YTaO}_{4}$ coatings were obtained at a substrate temperature of $900{ }^{\circ} \mathrm{C}$. Alloying with $\mathrm{ZrO}_{2}$ resulted in the growth of $M^{\prime}$ along with $t-\mathrm{Zr}(\mathrm{Y}, \mathrm{Ta}) \mathrm{O}_{2}$ for $\leq 15 \mathrm{~mol} \%$, while for $\geq 28 \mathrm{~mol} \%, \mathrm{ZrO}_{2}$ X-ray diffraction (XRD) phase-pure metastable $t$ was formed, which may be caused by small grain sizes and/or kinetic limitations. The former phase region transformed into $M^{\prime}$ and $M$ and the latter to an $M^{\prime}+t$ and $M+t$ phase region upon annealing to 1300 and $1650{ }^{\circ} \mathrm{C}$, respectively. In addition to $M$ and $t, T-\mathrm{YTa}(\mathrm{Zr}) \mathrm{O}_{4}$ phase fractions were observed at room temperature for $\mathrm{ZrO}_{2}$ contents $\geq 28 \mathrm{~mol} \%$ after annealing to $1650{ }^{\circ} \mathrm{C}$. $T$ phase fractions increased during in situ heating XRD at $80{ }^{\circ} \mathrm{C}$. At $1650{ }^{\circ} \mathrm{C}$, a reaction with the $\alpha-\mathrm{Al}_{2} \mathrm{O}_{3}$ substrate resulted in the formation of $\mathrm{AlTaO}_{4}$ and an $\mathrm{Al}-\mathrm{Ta}-\mathrm{Y}-\mathrm{O}$ compound.
\end{abstract}

Keywords: yttrium tantalate; zirconia; thermal barrier coatings; PVD; phase stability

\section{Introduction}

Thermal barrier coatings (TBCs) are commonly used in gas turbines to protect metallic components from excessive temperatures. TBCs enable higher operating temperatures and thereby enhance performance and energy efficiency while improving durability [1,2]. $\mathrm{ZrO}_{2}$ alloyed with $\approx 8 \mathrm{~mol} \% \mathrm{YO}_{1.5}$ (YSZ) to stabilize the tetragonal structure is the most commonly used TBC nowadays [3,4]. To further improve the sustainability and lifetimes of turbine engine components, new materials for TBCs have to be identified, surpassing the high fracture toughness of approximately $40 \mathrm{~J} \cdot \mathrm{m}^{-2}$ and thermal stability of up to $1300{ }^{\circ} \mathrm{C}$ of YSZ while reducing thermal conductivity of approximately $2 \mathrm{~W} \cdot \mathrm{m}^{-1} \mathrm{~K}^{-1}$ as well as minimizing corrosion by molten deposits [2,4,5].

The $\mathrm{Y}_{2} \mathrm{O}_{3}-\mathrm{Ta}_{2} \mathrm{O}_{5}-\mathrm{ZrO}_{2}$ system has gained attention as a promising candidate for improved TBCs. The pseudo binary $\mathrm{YTaO}_{4}-\mathrm{ZrO}_{2}$ is of particular interest due to reports of high fracture toughness [4,6] paired with lower thermal conductivity [5,7], superior thermal stability $[4,8]$, and improved resistance to corrosion $[4,9]$ compared to $\mathrm{YSZ}_{\text {. }} \mathrm{YTaO}_{4}$ is a polymorphous material reported to exhibit two different monoclinic [10,11] as well as two tetragonal structures [12]. The crystal structures of the phases are depicted in Figure 1. Heinze et al. [13] and Zhang et al. [14] predicted by ab initio approaches the monoclinic $M^{\prime}$ phase (space group P2/a) to be the thermodynamically stable configuration at $0 \mathrm{~K}$. At approximately $1450{ }^{\circ} \mathrm{C}$, a reconstructive phase transformation to a tetragonal scheelite structure $T$ (space group $\mathrm{I}_{1} / \mathrm{a}$ ) occurs, altering the Ta coordination from six-fold to eight-fold $[12,15]$. The compound melts congruently at $\approx 2044{ }^{\circ} \mathrm{C}$ [16]. Upon cooling, 
the scheelite phase experiences a second-order displacive phase transition at $1426 \pm 7{ }^{\circ} \mathrm{C}$ to the monoclinic $M$ phase (space group I2) $[6,8,10]$. Hence, the $M$ and $T$ phases are structurally closely related. Phase formation modeling by Zhang et al. [14] revealed only a small difference in total Gibbs energies for $M^{\prime}$ and $M$ of $-0.121 \mathrm{~kJ} \cdot \mathrm{mol}^{-1}$, whereas a large energy barrier for the diffusion of $Y$ of $3.26 \mathrm{eV}$ is hindering the $M$ to $M^{\prime}$ phase transition, indicating that $M$ is a metastable phase, as the transformation to the thermodynamically stable $M^{\prime}$ phase appears to be kinetically limited. Mather and Davies [12] have observed the formation of a metastable $T^{\prime}$ phase (space group $\mathrm{P} 4_{2} / \mathrm{nmc}$ ) in between 700 and $850{ }^{\circ} \mathrm{C}$ during heating of initially amorphous samples. This phase was described as a tetragonal distorted form of cubic fluorite with random cation distribution [12]. However, this was not reproduced by others $[15,17]$. Whereas the $M$ phase is considered as a potential TBC due to its low thermal conductivity $[5,7,18]$ and ferroelastic toughening $[4,6,8], M^{\prime}$ is of interest as X-ray phosphor in medical diagnostics because of its shorter Ta-O bonds, which enhance the charge-transfer processes utilized in luminescence $[19,20]$.

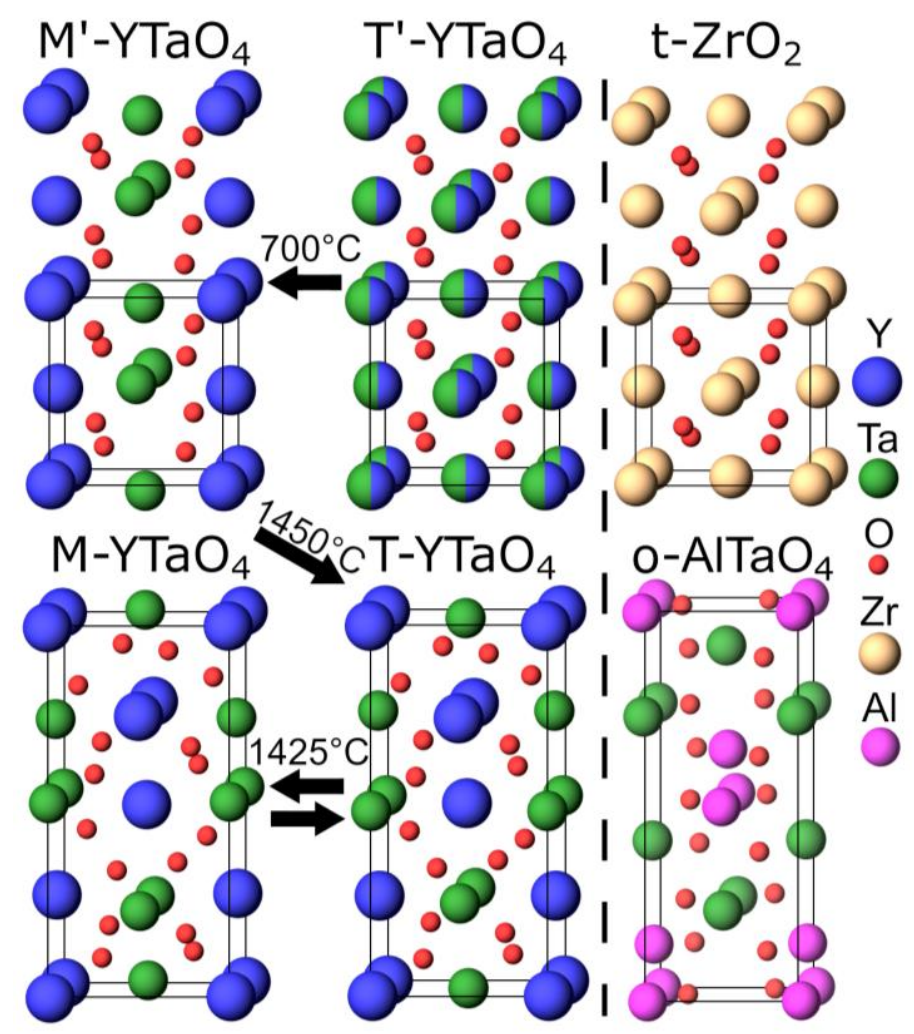

Figure 1. Structures of $\mathrm{M}^{\prime}-, \mathrm{M}-, \mathrm{T}^{\prime}-, \mathrm{T}-\mathrm{YTaO}_{4}, \mathrm{t}-\mathrm{ZrO}_{2}$, and o- $\mathrm{AlTaO}_{4}$ phases with indicated transition pathways and temperatures based on experimental findings by $[8,12,15]$.

The influence of alloying $\mathrm{ZrO}_{2}$ to $\mathrm{YTaO}_{4}$ has previously been studied for sintered samples. Figure 2a depicts the pseudo-binary phase diagram of $\mathrm{YTaO}_{4}-\mathrm{ZrO}_{2}$ by Gurak et al. [21]. Along the pseudo-binary $\mathrm{YTaO}_{4}-\mathrm{ZrO}_{2}$, up to $25-28 \mathrm{~mol} \% \mathrm{ZrO}_{2}$ can be solved in $M$ - as well as in $M^{\prime}-\mathrm{YTaO}_{4}[15,21]$. Gurak et al. reported that increasing $\mathrm{ZrO}_{2}$ concentrations lower the $M$ to $T$ transformation temperature to $450 \pm 20^{\circ} \mathrm{C}$ [21]. However, Flamant et al. observed the transformation temperature for the $M^{\prime}$ to $T$ transformation to remain at approximately $1450{ }^{\circ} \mathrm{C}$ for varying $\mathrm{ZrO}_{2}$ contents [15]. On the $\mathrm{Zr}$-rich side, $t-\mathrm{Zr}(\mathrm{Y}, \mathrm{Ta}) \mathrm{O}_{2}$ (space group $\mathrm{P}_{2} / \mathrm{nmc}$ ) remains phase pure due to a composition of approximately $65 \mathrm{~mol} \% \mathrm{ZrO}_{2}[4,22]$. Minor $\mathrm{YTaO}_{4}$ concentrations lead to the formation of monoclinic $\mathrm{ZrO}_{2}$ upon cooling [21,22]. $\mathrm{Y}^{3+}$ and $\mathrm{Ta}^{5+}$ stabilize the $t$ phase, resulting in a non-transformable $t$ phase region. As $\mathrm{Zr}^{4+}$ is substituted in equal parts by $\mathrm{Y}^{3+}$ and $\mathrm{Ta}^{5+}$, the net charge of the cations is compensated, and thus, other than for YSZ, no vacancy formation is necessary [23]. Hence, secondary phases are formed upon the excess of a few atomic percent of $Y$ or Ta along 
the whole $\mathrm{YTaO}_{4}-\mathrm{ZrO}_{2}$ pseudo binary [24,25]. In between the $M$ and $t$ solid solutions exists a two-phase region of $M$ and $t$ up to $450 \pm 20^{\circ} \mathrm{C}$ with $M$ transforming to $T$ at higher temperatures [21].
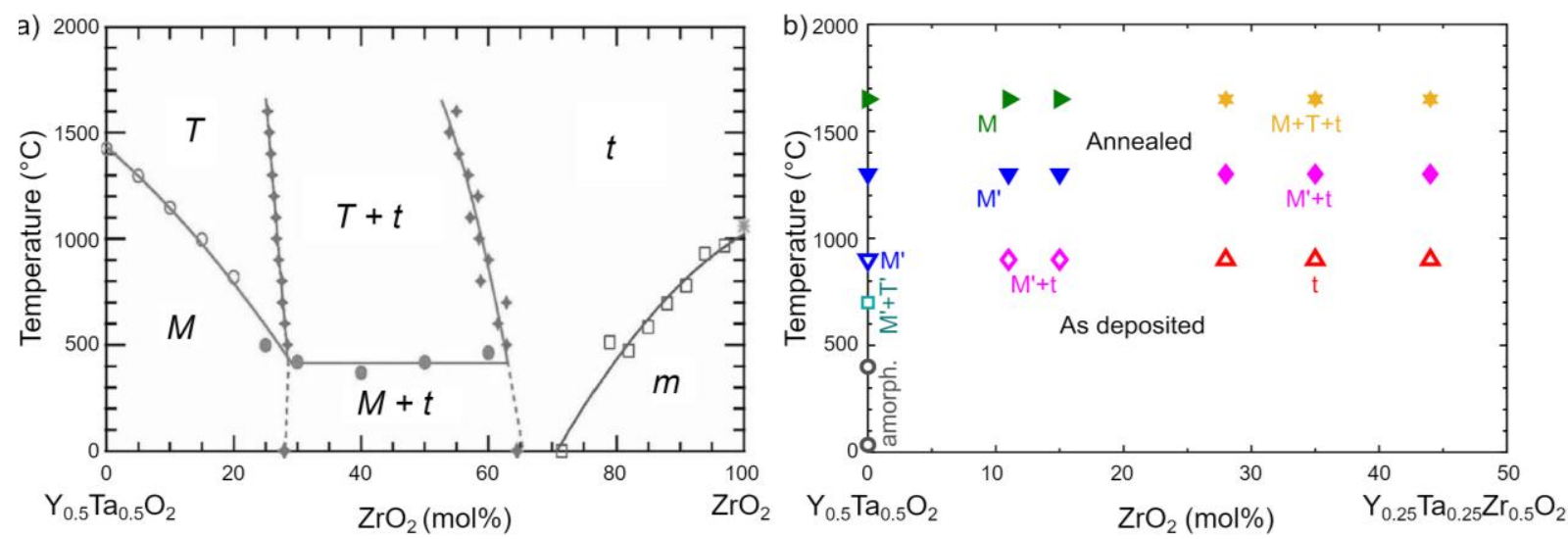

Figure 2. (a) Phase diagram along the $\mathrm{YTaO}_{4}-\mathrm{ZrO}_{2}$ pseudo binary adapted from Gurak et al. [21]; (b) Phases observed in this work for as-deposited samples (open symbols) synthesized at indicated substrate temperatures as well as samples annealed (filled symbols) at 1300 and $1650{ }^{\circ} \mathrm{C}$ for various $\mathrm{ZrO}_{2} \mathrm{~mol} \%$.

There has been significant progress in characterizing the $\mathrm{Y}_{2} \mathrm{O}_{3}-\mathrm{Ta}_{2} \mathrm{O}_{5}-\mathrm{ZrO}_{2}$ system. However, studies are almost exclusively performed on sintered bulk samples or powders $[4,5,7,8,15-19,21,22,24-26]$. Physical vapor deposition (PVD) or thermal spraying are commonly employed for depositions of TBCs. Phase formation in PVD may vary significantly from observations made during typical bulk sintering techniques due to the enhancement of surface diffusion by impinging atoms and ions. Nevertheless, experimental work on electron beam (EB)-PVD coatings has only been published for $\mathrm{Y}_{0.2} \mathrm{Ta}_{0.2} \mathrm{Zr}_{0.6} \mathrm{O}_{2}$ [27] and other $\mathrm{ZrO}_{2}$-rich systems with partial [27] or complete [28] substitution of $\mathrm{Y}$ by $\mathrm{Yb}$. In this work, the phase formation of sputtered $\mathrm{Y}_{(1-\mathrm{x}) / 2} \mathrm{Ta}_{(1-\mathrm{x}) / 2} \mathrm{Zr}_{\mathrm{x}} \mathrm{O}_{2}$ coatings with $\mathrm{ZrO}_{2}$ contents from 0 to $44 \mathrm{~mol} \%$ is studied systematically for the first time. To this end, a combinatorial reactive magnetron sputtering approach was employed to efficiently screen the effect of $\mathrm{ZrO}_{2}$ incorporation and substrate temperature on the phase formation as well as on the thermal stability.

\section{Materials and Methods}

$\mathrm{Y}_{(1-\mathrm{x}) / 2} \mathrm{Ta}_{(1-\mathrm{x}) / 2} \mathrm{Zr}_{\mathrm{x}} \mathrm{O}_{2}$ coatings were synthesized by reactive direct current magnetron sputtering (DCMS) in a laboratory-scale deposition system by a combinatorial approach, as schematically depicted in Figure 3. 99.9\% pure metallic Y, Ta, and $\mathrm{Zr}$ targets (50 mm diameter, $5 \mathrm{~mm}$ height) were located at a target to substrate distance of $100 \mathrm{~mm}$. The single crystalline $\alpha-\mathrm{Al}_{2} \mathrm{O}_{3}$ (0001) substrates (Siegert Wafer, Aachen, Germany) exhibited a diameter of $50.8 \mathrm{~mm}$ and were kept at floating potential. The target power density was set to $10.2 \mathrm{~W} \mathrm{~cm}{ }^{-2}$ for $\mathrm{Y}$ and Ta, whereas it was varied from 0 to $10.2 \mathrm{~W} \cdot \mathrm{cm}^{-2}$ for Zr. The power was applied for a deposition time of $4 \mathrm{~h}$ using two ENI RPG-50E (MKS Instruments, Andover, MA, USA) and a MDX-10K (Advanced Energy, Fort Collins, CO, USA) power supplies. Samples were deposited without intentional substrate heating as well as at temperatures of 400,700 , and $900^{\circ} \mathrm{C}$. The base pressure at the employed substrate temperatures was below $2 \times 10^{-4} \mathrm{~Pa}$ for all depositions. In order to obtain stoichiometric oxide films, the $\mathrm{Ar}$ (purity 6.0) and $\mathrm{O}_{2}$ (5.0) partial pressures were set to 0.1 and $0.3 \mathrm{~Pa}$, respectively.

After deposition, approximately $4 \times 4 \mathrm{~mm}^{2}$ pieces were cut out of the combinatorial sample at a central location of the wafer with stoichiometric $\mathrm{Y}_{(1-\mathrm{x}) / 2} \mathrm{Ta}_{(1-\mathrm{x}) / 2} \mathrm{Zr}_{\mathrm{x}} \mathrm{O}_{2}$ compositions. These samples were annealed in $\mathrm{Ar}$ (6.0) atmosphere in a Jupiter STA $449 \mathrm{C}$ calorimeter (Netzsch, Selb, Germany). Heat treatments were performed for $1 \mathrm{~h}$ at a heating and cooling rate of $40 \mathrm{~K} \cdot \mathrm{min}^{-1}$. The temperatures of 1300 and $1650{ }^{\circ} \mathrm{C}$ were selected above 
the synthesis temperature of $900{ }^{\circ} \mathrm{C}$, with one being below and one above $\mathrm{M}^{\prime} / \mathrm{M}$ to the $\mathrm{T}$ phase transition temperature.

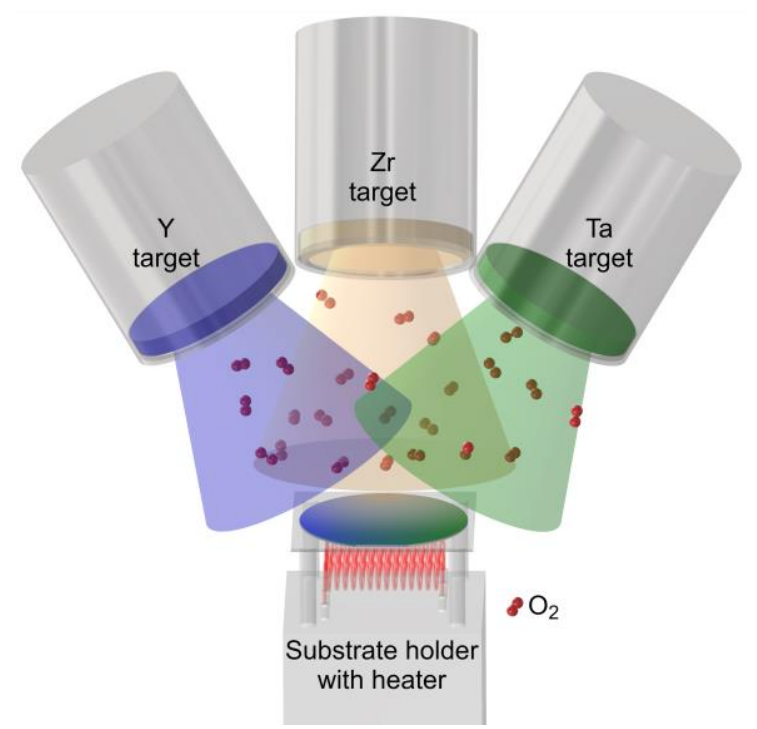

Figure 3. Schematic representation of deposition setup for reactive combinatorial magnetron sputtering of $\mathrm{Y}, \mathrm{Ta}$, and $\mathrm{Zr}$.

The coatings were characterized regarding phase formation by X-ray diffraction (XRD) in an AXS D8 Discover (Bruker, Billerica, MA, USA) equipped with a General Area Detector Diffraction System (GADDS) using an incident angle of $15^{\circ}$. A Cu $\mathrm{K}_{\alpha}$ radiation source was operated at a current and voltage of $40 \mathrm{~mA}$ and $40 \mathrm{kV}$, respectively. The reference XRD patterns employed for phase identification are given in Table 1. For in situ heating XRD experiments, an Anton Paar DHS 1100 heating stage with a graphite dome was installed into the diffractometer. In situ heating experiments were conducted in vacuum at a pressure below $10^{-2}$ mbar up to a sample temperature of $825^{\circ} \mathrm{C}$. A thermocouple was pressed onto the sample surface in order to measure sample temperatures.

The chemical composition of the coatings was determined by energy-dispersive $\mathrm{X}$ ray analysis (EDX) in a TM4000Plus scanning electron microscope (SEM) (Hitachi, Chiyoda, Japan) equipped with a Quantax75 EDX detector (Bruker, Billerica, MA, USA). For quantification, a reference measurement was performed by wavelength-dispersive $X$-ray spectroscopy (WDX) in a JXA-8530F microprobe (JEOL, Akishima, Japan) equipped with a field emission electron gun. Prior to the WDX measurement, a carbon coating was applied onto the samples to reduce electrostatic charging effects. An additional measurement on a non-carbon-coated part of the sample was carried out determining an upper limit for $\mathrm{C}$ contamination of $\approx 2.5$ at.\%. In this work, compositions are given as mole percent of the single cation formula units $\mathrm{Y}_{0.5} \mathrm{Ta}_{0.5} \mathrm{O}_{2}$ and $\mathrm{ZrO}_{2}$.

Table 1. List of abbreviations for phases including compound, space group, and International Centre for Powder Diffraction (ICDD) Power Diffraction File (PDF) number or literature for used XRD references.

\begin{tabular}{cccc}
\hline Abbreviation & Compound & Space Group & PDF Number \\
\hline$M^{\prime}$ & $\mathrm{YTaO}_{4}$ & $\mathrm{P} 2 / \mathrm{a}$ & $00-024-1425$ \\
$M$ & $\mathrm{YTaO}_{4}$ & $\mathrm{I} 2$ & $00-024-1415$ \\
$T^{\prime}$ & $\mathrm{YTaO}_{4}$ & $\mathrm{P}_{2} / \mathrm{nmc}$ & $00-050-0846$ \\
$T$ & $\mathrm{YTaO}_{4}$ & $\mathrm{I} 4_{1} / \mathrm{a}$ & Feng et al. [6] \\
$T$ & $\mathrm{ZrO}_{2}$ & $\mathrm{P}_{2} / \mathrm{nmc}$ & $00-043-0308$ \\
$O$ & $\mathrm{AlTaO}_{4}$ & $\mathrm{Pbcn}$ & $01-079-2410$ \\
\hline
\end{tabular}


Spatially resolved chemical compositions were measured by laser-assisted threedimensional atom probe tomography (3D-APT) in a local electrode atom probe 4000X HR (CAMECA, Madison, WI, USA). The $\mathrm{YTaO}_{4}$ thin film $\left(0 \mathrm{~mol} \% \mathrm{ZrO}_{2}\right)$ was measured with $50 \mathrm{pJ}$ laser pulse energy, $125 \mathrm{kHz}$ laser pulse frequency, and $60 \mathrm{~K}$ base temperature. Since these conditions resulted in immediate fracture of the thin films with $35 \mathrm{~mol} \% \mathrm{ZrO}_{2}$, the laser pulse energy and base temperature were reduced to $10 \mathrm{pJ}$ and $30 \mathrm{~K}$, respectively, for the $\mathrm{Zr}$-containing thin films. The detection rate was set to $0.5 \%$ for all three measurements, and at least 5 million ions were acquired. Data analysis was carried out using IVAS 3.8.0.

Needle-like APT specimens were prepared in a standard lift-out procedure [29] by focused ion beam (FIB) in a Helios Nanolab 660 dual-beam microscope (FEI, Hillsboro, OR, USA). Furthermore, this dual-beam microscope was used for top-view imaging employing a back-scattered electron (BSE) detector as well as for preparation of lamellae and subsequent scanning transmission electron microscopy (STEM) using a STEM III detector. Chemical compositions of lamellae were measured by standardless EDX with an Octane Elect Plus (EDAX, Mahwah, NJ, USA).

The arithmetic mean roughness was acquired in a VK-9700 laser optical microscope (Keyence, Osaka, Japan). Nanoindentation measurements were performed on a TI-900 TriboIndenter (Hysitron, Minneapolis, MN, USA) equipped with a Berkovich diamond tip (Hysitron, Minneapolis, MN, USA). The tip area function was calibrated on fused silica. The applied load of $1200 \mu \mathrm{N}$ resulted in maximum indentation depths below $10 \%$ of the film thickness. The elastic modulus was determined according to the method by Oliver and Pharr [30] for a minimum of 49 indents per sample. A Poisson's ratio of 0.29 [14] was used.

\section{Results and Discussion}

\subsection{Effect of Substrate Temperature on $\mathrm{YTaO}_{4}$ Depositions}

The phase formation of the as-deposited $\mathrm{YTaO}_{4}$ coatings without intentional heating as well as at substrate temperatures of 400,700 , and $900{ }^{\circ} \mathrm{C}$ was investigated by XRD as depicted in Figure 4 . For the diffraction experiments, the as-deposited combinatorial coatings were screened for locations exhibiting $Y$ to Ta ratios of 1 based on EDX measurements employing the WDX reference measurement as standard.

Coatings deposited at substrate temperatures of $400{ }^{\circ} \mathrm{C}$ or below are XRD amorphous. At a substrate temperature of $700{ }^{\circ} \mathrm{C}$, several broad peaks consistent with the reported peak positions of $M^{\prime}$ appear. The $M^{\prime}(-111)$ and (200) peaks at 28.4 and $34.0^{\circ}$ exhibit broadening toward larger $2 \theta$ values, suggesting the presence of the metastable $T^{\prime}$-phase. At a nominal substrate temperature of $900^{\circ} \mathrm{C}$, crystallinity is further improved with all peaks coinciding with peak positions of $M^{\prime}$. Due to a preferred $(-111)$ orientation of the sample, several peaks such as the (011) and (110) are only observed after tilting the sample (not shown here). Hence, the results indicate the formation of an XRD phasepure $\mathrm{M}^{\prime}$ coating. These observations are in agreement with Mather and Davies [12] who identified an XRD amorphous structure at $600{ }^{\circ} \mathrm{C}, \mathrm{T}^{\prime}$ formation at $800{ }^{\circ} \mathrm{C}$, and a phase mixture of $T^{\prime}$ and $M^{\prime}$ at $900{ }^{\circ} \mathrm{C}$ for sol-gel-prepared $\mathrm{YTaO}_{4}$. In this work, the phase mixture of $M^{\prime}$ and $T^{\prime}$ was already observed at $700^{\circ} \mathrm{C}$. It is reasonable to assume that ion bombardment-induced surface diffusion occurring during sputtering causes the reduced phase formation temperature compared to bulk diffusion dominated processes commonly employed in previous studies. This has previously been observed for $\mathrm{Mo}_{2} \mathrm{BC}$ [31] as well as $\mathrm{Cr}_{2} \mathrm{AlC}[32,33]$. Furthermore, the formation of an XRD phase-pure $M^{\prime}$ coating is observed at $900{ }^{\circ} \mathrm{C}$, which is consistent with the literature, as the formation of $M^{\prime}$ instead of $M$ is widely reported for synthesis methods below the $M^{\prime}-T$ transformation temperature of $\approx 1450{ }^{\circ} \mathrm{C}[10,12,15]$. 


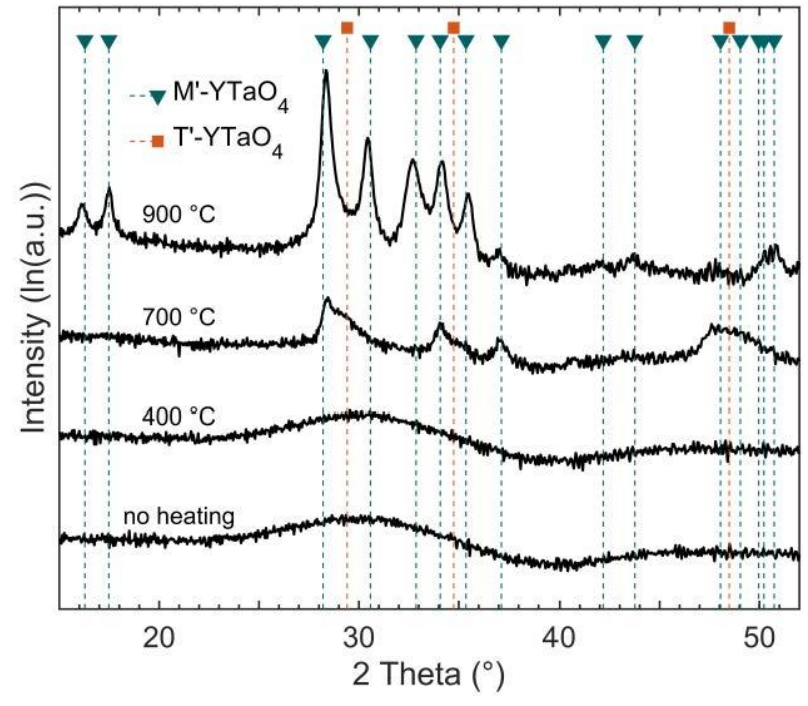

Figure 4. Diffractograms of $\mathrm{YTaO}_{4}$ coatings deposited at indicated substrate temperatures.

The coating deposited at $900{ }^{\circ} \mathrm{C}$ exhibits a thickness of $970 \pm 5 \mathrm{~nm}$ with a dense, fibrous microstructure, as shown in the STEM image in Figure 5b. APT measurements (Figure 6a-c) indicate a random distribution of $\mathrm{Y}, \mathrm{Ta}$, and $\mathrm{O}$ with Pearson correlation coefficients $\mu \leq 0.06$ within the analyzed $1.9 \times 10^{6}$ atoms [34]. Hence, APT analysis supports the notion of the exclusive formation of the $\mathrm{YTaO}_{4}$ phases $\left(T^{\prime}, M^{\prime}, M\right.$, or $\left.T\right)$ without precipitates of $\mathrm{Y}_{3} \mathrm{TaO}_{7}$ or $\mathrm{YTa}_{7} \mathrm{O}_{19}$, which have been reported to form for Ta or $\mathrm{Y}$ deficiencies of few atomic percent $[24,26]$.
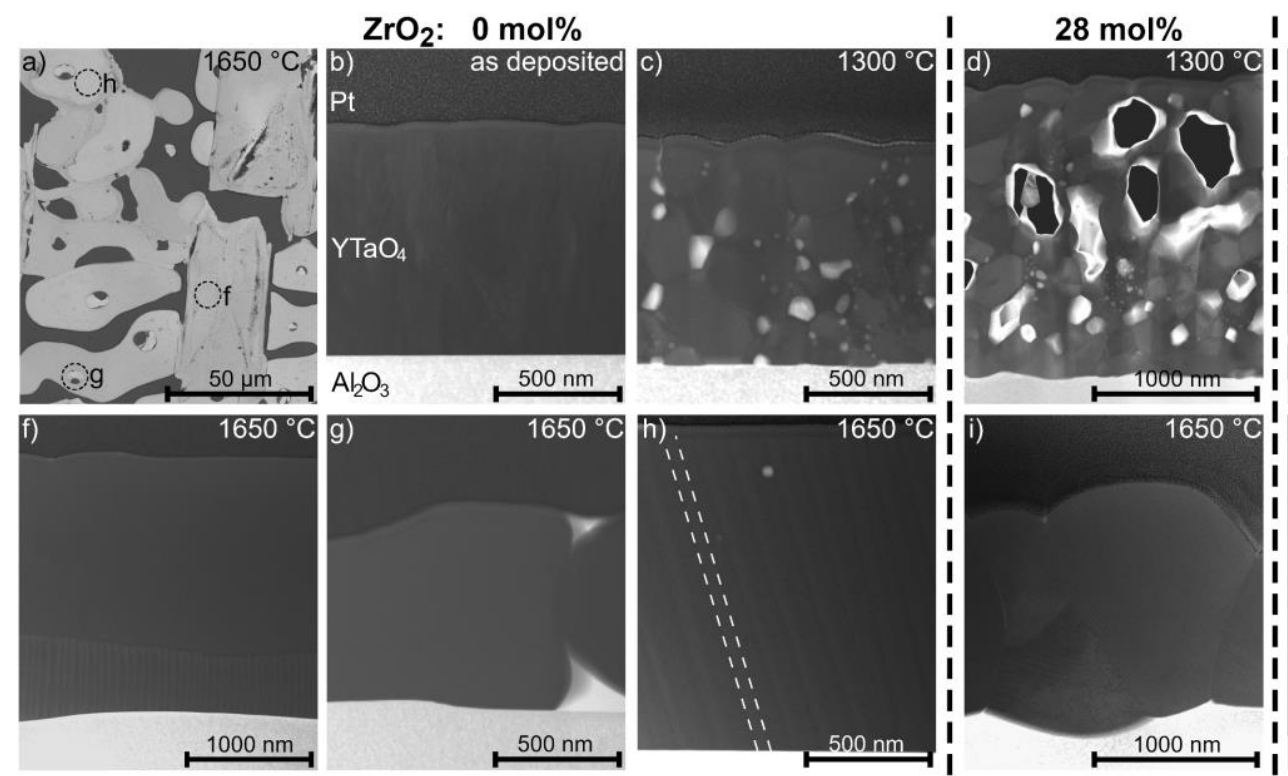

$44 \mathrm{~mol} \%$
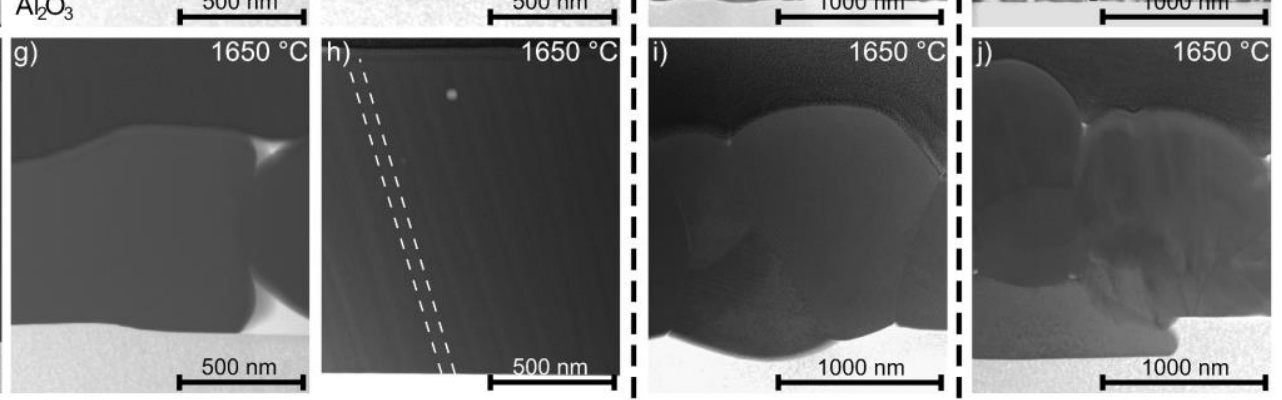

Figure 5. (a) Top-view SEM image of $\mathrm{ZrO}_{2}$ free sample after annealing at $1650{ }^{\circ} \mathrm{C}$; Dark field STEM images of cross-sections prepared by focused ion beam (FIB) milling of as-deposited (b) as well as annealed for $1 \mathrm{~h}$ at $1300{ }^{\circ} \mathrm{C}(\mathbf{c}-\mathbf{e})$ and $1650{ }^{\circ} \mathrm{C}(\mathbf{f}-\mathbf{j})$ for 0,28 , and $44 \mathrm{~mol} \% \mathrm{ZrO}_{2}$. Locations of cross-sections for $(\mathbf{f}-\mathbf{h})$ are indicated in a. Dashed lines in $h$ highlight a twin. 

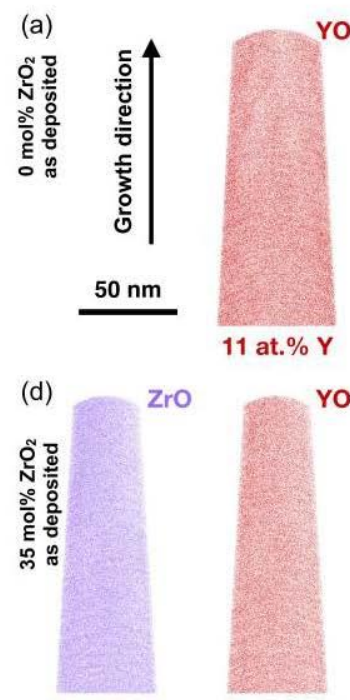

14 at. $\% \mathrm{Zr}$

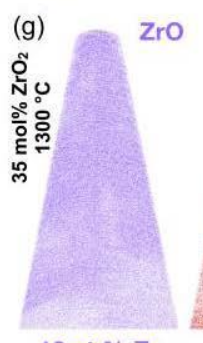

16 at. $\% \mathrm{Zr}$
11 at. $\%$ Y

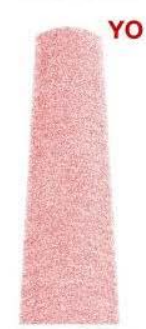

9 at.\% Y

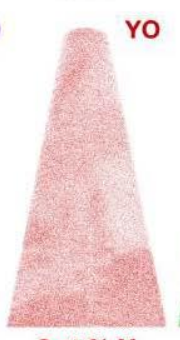

8 at. $\%$ Y

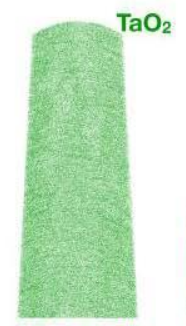

16 at. $\% \mathrm{Ta}$

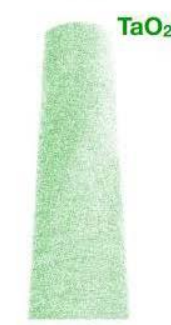

9 at. $\% \mathrm{Ta}$

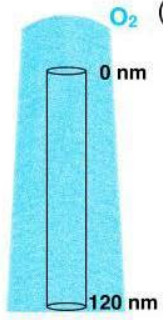

73 at. $\% 0$

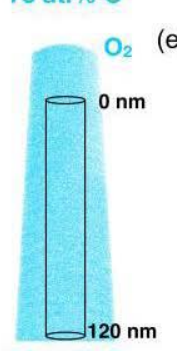

68 at. $\% 0$
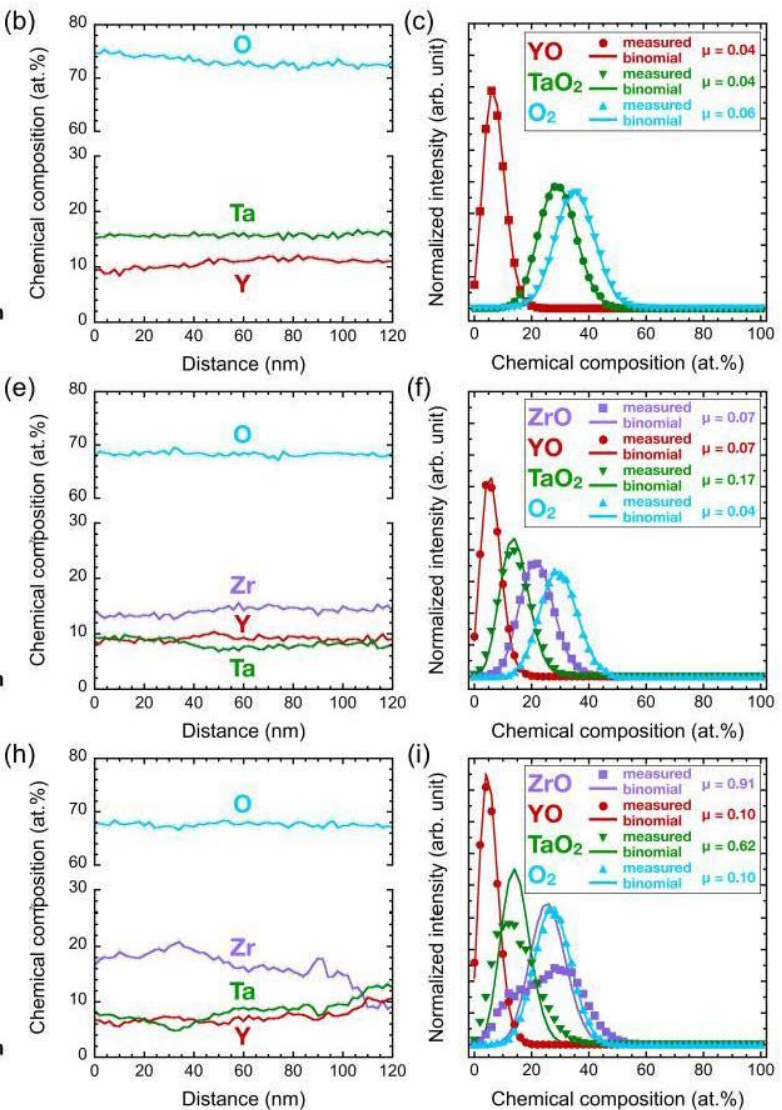

Figure 6. Spatially resolved chemical composition analysis by atom probe tomography (APT) of as-deposited samples with $0 \mathrm{~mol} \% \mathrm{ZrO}_{2}(\mathbf{a}-\mathbf{c})$ and $35 \mathrm{~mol} \% \mathrm{ZrO}_{2}(\mathbf{d}-\mathbf{f})$ as well as a sample with $35 \mathrm{~mol} \% \mathrm{ZrO}_{2}$ annealed at $1300{ }^{\circ} \mathrm{C}$ (g-i); Reconstructions of molecular ions in $(\mathbf{a}, \mathbf{d}, \mathbf{g})$ are provided as $20 \mathrm{~nm}$ slices with a length of $150 \mathrm{~nm}$; Concentration profiles within cylinders indicated in $(\mathbf{a}, \mathbf{d}, \mathbf{g})$ are shown in $(\mathbf{b}, \mathbf{e}, \mathbf{h})$; Frequency distribution analyses with Pearson correlation coefficients $\mu$ are given in $(\mathbf{c}, \mathbf{f}, \mathbf{i})$, and the measured distributions (data points) are compared to a random, binomial distribution (lines).

\subsection{Effect of Zirconia Alloying on Phase Formation of As-Deposited Coatings}

$\mathrm{Y}_{(1-\mathrm{x}) / 2} \mathrm{Ta}_{(1-\mathrm{x}) / 2} \mathrm{Zr}_{\mathrm{x}} \mathrm{O}_{2}$ coatings were deposited at $900{ }^{\circ} \mathrm{C}$ with varying $\mathrm{Zr}$ content and were subsequently analyzed by XRD at EDX measured chemical compositions of $0,11,15$, 28, 35, and $44 \mathrm{~mol} \% \mathrm{ZrO}_{2}$, as shown in Figure 7a. The thickness for the samples deposited at a constant deposition time of $4 \mathrm{~h}$ range from $970 \pm 5 \mathrm{~nm}(4.0 \mathrm{~nm} / \mathrm{min})$ for the coating without $\mathrm{Zr}$ up to $1423 \pm 4 \mathrm{~nm}(5.9 \mathrm{~nm} / \mathrm{min})$ for the sample with $44 \mathrm{~mol} \% \mathrm{ZrO}_{2}$, with the deposition rate given in brackets. The low deposition rates are expected to be caused by the targets running in poisoned mode and the possible thermal evaporation from the substrate due to the high temperature.

As described above, coatings deposited at $900{ }^{\circ} \mathrm{C}$ with $0 \mathrm{~mol} \% \mathrm{ZrO}_{2}$ exhibit XRD phase-pure $M^{\prime}-\mathrm{YTaO}_{4}$. For increasing $\mathrm{ZrO}_{2}$ contents up to $15 \mathrm{~mol} \%$, the formation of an $M^{\prime}$ solid solution phase with declining diffracted intensities and a peak shift of the $(-111)$ peak at $28.4^{\circ}$ toward larger diffraction angles is observable. $\mathrm{Zr}$ was reported to equally substitute $\mathrm{Y}$ and $\mathrm{Ta}$ in the monoclinic $\mathrm{YTaO}_{4}$ structures, where the slightly smaller ion radius of $\mathrm{Zr}^{4+}$ (8.4 $\AA$ ) compared to the average ion radius of $\mathrm{Y}^{3+}(10.2 \AA)$ and $\mathrm{Ta}^{5+}(7.4 \AA)$ [35] being $8.7 \AA$ results in a reduction of the unit cell volume and thus a peak shift toward larger diffraction angles. The presence of a tetragonal second phase is apparent at $15 \mathrm{~mol} \% \mathrm{ZrO}_{2}$ and may already be formed for $11 \mathrm{~mol} \% \mathrm{ZrO}_{2}$, as indicated by the pronounced shoulder of the $(-111)$ peak toward larger $2 \theta$ values. Hence, the solubility limit of $\mathrm{ZrO}_{2}$ in as-deposited $M^{\prime}$ solid solutions appears to be $<15 \mathrm{~mol} \%$, which is significantly lower compared to the solubility limit of 25 to $28 \mathrm{~mol} \% \mathrm{ZrO}_{2}$ reported for sintered $M^{\prime}$ samples by Flamant et al. [15]. 
Further increase of $\mathrm{ZrO}_{2}$ to $28 \mathrm{~mol} \%$ and up to the maximum synthesized concentration of $44 \mathrm{~mol} \% \mathrm{ZrO}_{2}$ results in the formation of a phase-pure $t-\mathrm{Zr}(\mathrm{Y}, \mathrm{Ta}) \mathrm{O}_{2}$ solid solution. The formation of a two-phase region of $t$ in combination with $M$ or $M^{\prime}$ phase has been reported for sintered samples with $\approx 25$ to $\approx 65 \mathrm{~mol} \% \mathrm{ZrO}_{2}[10,12,15-18]$. However, Van Sluytman et al. [27] deposited tetragonal $\mathrm{Y}_{0.2} \mathrm{Ta}_{0.2} \mathrm{Zr}_{0.6} \mathrm{O}_{2}$ coatings by EB-PVD consisting of a $t$-phase matrix with $T$-phase precipitates with distinguishable chemical compositions. APT analysis of the thin film with $35 \mathrm{~mol} \% \mathrm{ZrO}_{2}$ (Figure $6 \mathrm{~d}-\mathrm{f}$ ) showed no major segregation of $\mathrm{Y}$, Ta, or $\mathrm{Zr}$ in the analyzed $1.5 \times 10^{6}$ atoms, supporting the notion of a single-phase coating. Coatings deposited in this work exhibit phase-pure $t$ in the $\mathrm{YTaO}_{4}-\mathrm{ZrO}_{2}$ system to an unprecedented low $\mathrm{ZrO}_{2}$ content of $28 \mathrm{~mol} \%$.

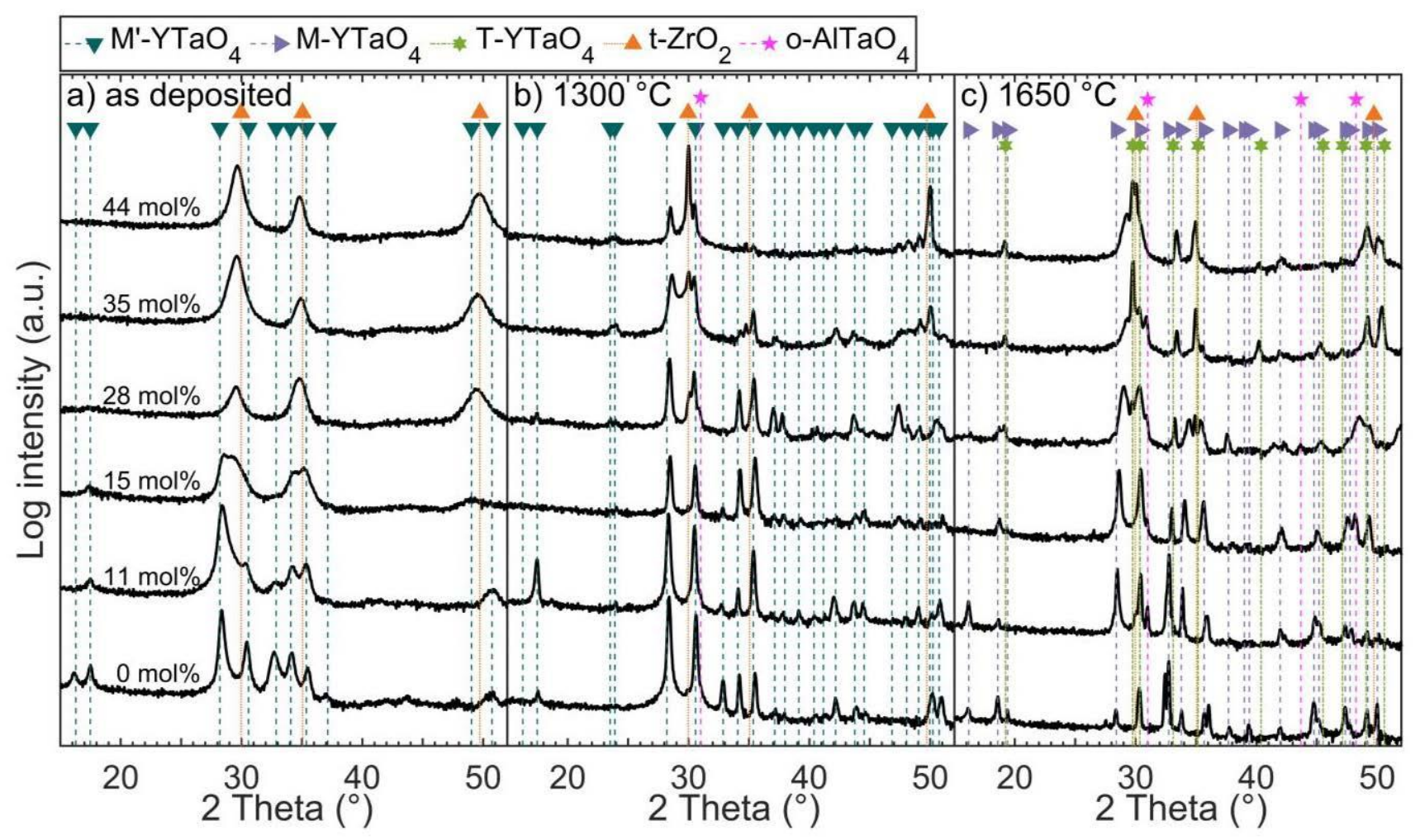

Figure 7. Diffractograms of $\mathrm{Y}_{(1-\mathrm{x}) / 2} \mathrm{Ta}_{(1-\mathrm{x}) / 2} \mathrm{Zr}_{\mathrm{x}} \mathrm{O}_{2}$ coatings with $\mathrm{x}$ ranging from 0 to 44 in (a) As-deposited, (b) Annealed for $1 \mathrm{~h}$ at $1300^{\circ} \mathrm{C}$, and (c) Annealed for $1 \mathrm{~h}$ at $1650{ }^{\circ} \mathrm{C}$ states.

Additions of $\mathrm{Y}$ and Ta into $\mathrm{ZrO}_{2}$ are well known to stabilize the high-temperature tetragonal phase $t-\mathrm{ZrO}_{2}$ and suppress monoclinic $m-\mathrm{ZrO}_{2}$, as depicted in the phase diagram in Figure $2 \mathrm{a}[4,21,22,36]$. Kim et al. reported tetragonal $\mathrm{Y}_{(1-\mathrm{x}) / 2} \mathrm{Ta}_{(1-\mathrm{x}) / 2} \mathrm{Zr}_{\mathrm{x}} \mathrm{O}_{2}$ to be stable independent of grain size for 78 to $84 \mathrm{~mol} \% \mathrm{ZrO}_{2}$, with analyzed grain sizes of up to $5 \mu \mathrm{m}$ [22]. This formation of the $t$ phase was explained by the introduction of local distortions due to the substitution of $\mathrm{Zr}$ by smaller $\mathrm{Ta}^{5+}$ and larger $\mathrm{Y}^{3+}$ cations [4] as well as low grain sizes, as was shown by Shukla and Seal [23]. $T^{\prime}$ was reported for the $Y$ and Ta rich side of the $\mathrm{YTaO}_{4}-\mathrm{ZrO}_{2}$ pseudo-binary by Mather and Davies [12], who observed $\mathrm{Zr}$ free $T^{\prime}-\mathrm{YTaO}_{4}$ at temperatures of approximately $800^{\circ} \mathrm{C}$. They described $T^{\prime}$ as a metastable tetragonal phase isostructural to $t$ but with disordered cation distribution, see Figure 1 , and speculated that this phase is stabilized by the Gibbs-Thomson effect. Small grain sizes are known to reverse the phase formation behavior during thin film synthesis compared to bulk processing, resulting in the stabilization of e.g., $\gamma^{-}$over $\alpha-\mathrm{Al}_{2} \mathrm{O}_{3}$ [37], wurtzite over face-centered cubic (Ti, AlN) [38] as well as $t$ over $m$ in unalloyed $\mathrm{ZrO}_{2}$ [23].

In our work, the formation of both $m-\mathrm{ZrO}_{2}$ as well as $M^{\prime}-Y \mathrm{TaO}_{4}$ is hindered. Whereas the suppression of $m$ may be due to alloying with $\mathrm{Y}$ and $\mathrm{Ta}$, it can be speculated that the suppression of $M^{\prime}$ is caused by small grain sizes, as was suggested by Mather and 
Davies [12] and/or by kinetically limited phase formation during magnetron sputtering. Evaluation of the broad diffraction peaks by Scherrer equation [39] yields crystallite sizes in between $15 \pm 3$ and $21 \pm 6 \mathrm{~nm}$ for as-deposited phase-pure $t-\mathrm{Zr}(\mathrm{Y}, \mathrm{Ta}) \mathrm{O}_{2}$ solid solutions. Furthermore, the employed synthesis temperature of $900{ }^{\circ} \mathrm{C}$ and the minute ion bombardment during coating deposition at floating potential is expected to result in kinetically limited growth, causing the formation of the metastable phases. However, while this is in line with experiences from other material systems [40] and with the observations made in this work, the data at hand does not provide irrevocable evidence for one of the mechanisms mentioned above to dominate the others.

\subsection{Effect of Annealing on Zirconia Alloyed $\mathrm{YTaO}_{4}$ Coatings}

Annealing for $1 \mathrm{~h}$ at 1300 and $1650{ }^{\circ} \mathrm{C}$ resulted in significant changes in ex situ measured diffractograms for all the compositions studied here (Figure $7 \mathrm{~b}$ ). For the sample without $\mathrm{ZrO}_{2}$, the diffractogram obtained after annealing at $1300{ }^{\circ} \mathrm{C}$ shows an increase in crystallinity reflected in a decrease in full width at half maximum, while all peaks indicate the presence of $M^{\prime}$, as it is the case for as deposited coatings. However, the texture of the film has changed, e.g., the (010) peak at $16.2^{\circ}$ is not visible. Cross-sectional STEM imaging of the as-deposited and $1300{ }^{\circ} \mathrm{C}$ annealed sample is shown in Figure 5b,c. The microstructure changes from fibrous grains growing perpendicular to the surface in the asdeposited state to a morphology containing larger, globular grains and a significant amount of pores that evolve at the grain boundaries. Annealing at $1650{ }^{\circ} \mathrm{C}$ resulted in further grain growth, with single grains expanding over the full height of the coating (Figure 5h). Furthermore, the observed grains exhibit twin domains after annealing at $1650^{\circ} \mathrm{C}$. These grains cover several $\mu \mathrm{m}$ of the substrate as visible in top-view SEM imaging in Figure 5a. Additionally, SEM and STEM revealed local dewetting of the sapphire substrate after heat treatment at $1650{ }^{\circ} \mathrm{C}$. The dark regions in Figure 5 a stem from the $\alpha-\mathrm{Al}_{2} \mathrm{O}_{3}$ substrate, which is exposed due to dewetting. Melting of any composition within the $\mathrm{YO}_{1.5}-\mathrm{TaO}_{2.5}$ system is not expected at $1650{ }^{\circ} \mathrm{C}$ according to phase diagrams proposed by Fernandez et al. [26] and Zhang et al. [14]. Hence, a solid-state dewetting process driven by differences in surface and interface energies and enabled by surface diffusion [41] is responsible for the exposure of the substrate.

XRD analysis revealed the transformation from $M^{\prime}$ to $M$ after annealing at $1650{ }^{\circ} \mathrm{C}$ (Figure 7c). The diffractogram of the $\mathrm{ZrO}_{2}$ free coating annealed at $1650^{\circ} \mathrm{C}$ exhibits peaks at $27.5^{\circ}, 32.4^{\circ}$, and $36.1^{\circ}$, not fitting to the $M$-phase. These may be linked to the observation of rectangular-shaped grains, shown in the SEM image in Figure 5a. EDX measured chemical compositions of a lamellae cut out of the arbitrary rounded shaped grains in Figure 5a are consistent with $\mathrm{YTaO}_{4}$. However, a lamella prepared from a rectangular-shaped grain contains a twinned grain with a composition fitting to $\mathrm{YTaO}_{4}$ above the $\alpha-\mathrm{Al}_{2} \mathrm{O}_{3}$ substrate and on top, a grain containing $\mathrm{Al}$ in addition to Ta-Y-O (Figure $5 \mathrm{f}$ ). These results suggest a reaction of the $\mathrm{Y}-\mathrm{Ta}-\mathrm{O}$ coating with the $\alpha-\mathrm{Al}_{2} \mathrm{O}_{3}$ substrate. The actual phase is yet to be identified, and there are no reports on a structure corresponding to the observed Y-Ta-Al-O composition available.

$\mathrm{YTaO}_{4}$ samples alloyed with 11 and $15 \mathrm{~mol} \% \mathrm{ZrO}_{2}$ and annealed at $1300{ }^{\circ} \mathrm{C}$ do not exhibit a peak broadening of the (-111) peak toward larger angles, as was seen for as deposited coatings. Thus, XRD indicates the formation of single-phase $M^{\prime}$ coatings after annealing. Likewise, heat treatment at $1650{ }^{\circ} \mathrm{C}$ results in the formation of $M$.

Annealing of as deposited XRD phase-pure $t$ samples with $\mathrm{ZrO}_{2}$ contents of $28 \mathrm{~mol} \%$ or higher at $1300{ }^{\circ} \mathrm{C}$ resulted in the formation of $M^{\prime}$ next to $t$ (Figure 7c). An increase in $\mathrm{ZrO}_{2}$ leads to an increase in the $t$ peak intensity at a $2 \theta$ value of $\approx 30.0^{\circ}$, which evolves from a shoulder of the (111) $M^{\prime}$ peak to the most prominent peak. The transformation from an as-deposited XRD single-phase $t$ to a two-phase coating is in good agreement with the observation of Zr-rich as well as Y- and Ta-rich regions with reduced $\mathrm{Zr}$ content observed by APT for $35 \mathrm{~mol} \% \mathrm{ZrO}_{2}$ only after annealing. This segregation is mirrored by an increase in the Pearson correlation coefficients for $\mathrm{ZrO}$ from 0.07 to 0.91 in as-deposited 
and $1300{ }^{\circ} \mathrm{C}$ annealed state, respectively (Figure $6 \mathrm{~d}-\mathrm{i}$ ). Correspondingly to previously discussed lower $\mathrm{ZrO}_{2}$ contents, heat treatment at $1650{ }^{\circ} \mathrm{C}$ resulted in the transformation of $M^{\prime}$ into $M$. However, the $t$-phase remains stable. Furthermore, a second tetragonal phase, the high temperature $T$ phase, is observed after cooling.

In situ heating XRD measurements up to approximately $825^{\circ} \mathrm{C}$ were performed in order to study the thermal stability of both as-deposited and annealed coatings (Figure 8). For as deposited coatings with 0 and $44 \mathrm{~mol} \% \mathrm{ZrO}_{2}$ consisting of $M^{\prime}$ and $t$, respectively, in situ heating did not result in measurable changes of the constitution up to $825^{\circ} \mathrm{C}$ but only in peak shifts due to thermal expansion. As no changes of the pre- and post-annealed coatings could be identified at room temperature, the obtained coatings are considered to be stable up to a temperature of $825^{\circ} \mathrm{C}$. The same observation was made for an $M^{\prime}$ and $t$ two-phase coating with $44 \mathrm{~mol} \% \mathrm{ZrO}_{2}$ after annealing at $1300{ }^{\circ} \mathrm{C}$ (Figure 8a-c). Coatings pre-annealed at $1650{ }^{\circ} \mathrm{C}$ with $\mathrm{ZrO}_{2}$ contents of 28 and $44 \mathrm{~mol} \% \mathrm{ZrO}_{2}$ showed a more complex behavior. At room temperature, the $44 \mathrm{~mol} \% \mathrm{ZrO}_{2}$-containing sample, which was annealed at $1650{ }^{\circ} \mathrm{C}$, exhibits a $T$ as well as a $t$ peak at $29.8^{\circ}$ and $30.1^{\circ}$, respectively, and broader $M$ peaks at $29.1^{\circ}$ and $30.4^{\circ}$ (Figure $8 \mathrm{~d}$ ). Upon heating, both $M$ peaks exhibit a decrease in intensity already at temperatures of $80^{\circ} \mathrm{C}$, while the $T$-phase peak gains intensity. The intensity of the $t$ peak is unaffected by the increase in temperature. At a temperature of approximately $480^{\circ} \mathrm{C}$, both $M$-phase peaks have disappeared, while the $T$ peak ceases to gain intensity upon further heating. A second T-phase peak emerged at $30.1^{\circ}$ out of the shoulder of the $t$ and declining $M$-phase peak. Upon cooling, all observed phase transformations are fully reversible. For a $\mathrm{ZrO}_{2}$ concentration of $28 \mathrm{~mol} \%$, a similar decrease and increase of the $M$ and $T$ phase were observed (Figure 8e). The peak corresponding to $t$, barely identifiable at room temperature, is clearly visible after $M$ transformed into $T$ upon heating.

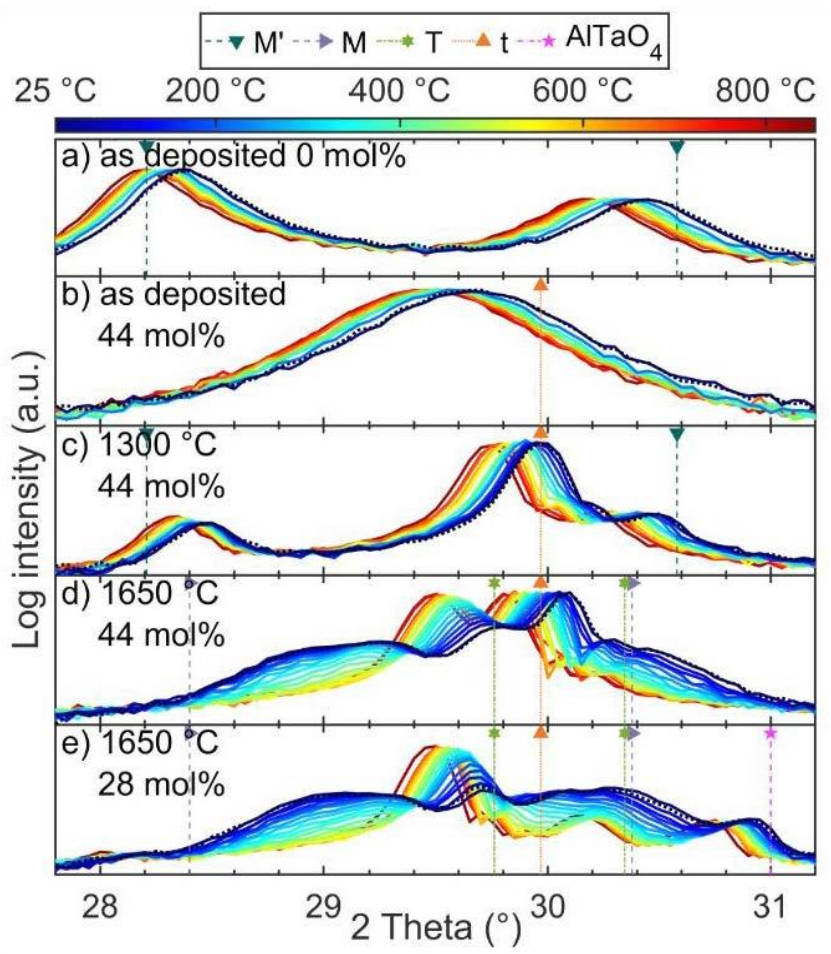

Figure 8. Diffractograms obtained during in situ heating experiments of as-deposited and preannealed $\mathrm{Y}_{(1-\mathrm{x}) / 2} \mathrm{Ta}_{(1-\mathrm{x}) / 2} \mathrm{Zr}_{\mathrm{x}} \mathrm{O}_{2}$ coatings. Dotted intensities represent measurements at room temperature after completed in situ heating.

Furthermore, a peak at $30.9^{\circ}$ with temperature-independent intensity at room temperature was observed. For various compositions annealed at $1650^{\circ} \mathrm{C}$ as well as for the coating composed of $28 \mathrm{~mol} \% \mathrm{ZrO}_{2}$ annealed at $1300^{\circ} \mathrm{C}$, this additional peak at $\approx 30.9^{\circ}$ was obtained in XRD diffractograms (Figure $7 b, c$ ). This may be ascribed to orthorhombic 
$\mathrm{AlTaO}_{4}$. Grains with a Ta-Al-O composition have also been observed in lamellae cut out of the vicinity of an $\mathrm{YTaO}_{4}$ grain for the $\mathrm{ZrO}_{2}$ free sample annealed to $1650{ }^{\circ} \mathrm{C}$ (Figure $5 \mathrm{~g}$ ). A significant increase in roughness at the substrate-coating interface was observed for grains exhibiting a Ta-Al-O or the previously discussed Ta-Y-Al-O composition (Figure 5f,g,i,j). To a lower extent, this roughness enhancement is also observable after annealing to $1300{ }^{\circ} \mathrm{C}$ (Figure $5 \mathrm{c}-\mathrm{e}$ ). However, this is not observed for as-deposited coatings or areas covered with $\mathrm{Al}$ free $M$ grains, as depicted in Figure $5 \mathrm{~h}$. Hence, it is inferred that the roughness enhancement is a consequence of the reaction of the coating with the $\alpha-\mathrm{Al}_{2} \mathrm{O}_{3}$ substrate during annealing.

EDX measured compositions of both of the above described Al containing impurity phases indicate $\mathrm{Y}$ depletion. Thus, the formation of these phases may be caused by deviations from the $\mathrm{Y}_{(1-\mathrm{x}) / 2} \mathrm{Ta}_{(1-\mathrm{x}) / 2} \mathrm{Zr}_{\mathrm{x}} \mathrm{O}_{2}$ composition. By their nature, combinatorially deposited coatings exhibit chemical gradients. Only comparably small $4 \times 4 \mathrm{~mm}^{2}$ pieces were annealed in this study in order to limit diffusion effects and influences of heavily overor understoichiometric regions. However, even this small sample size allows chemical gradients of approximately \pm 1 at. $\%$. Hence, the reaction with $\alpha-\mathrm{Al}_{2} \mathrm{O}_{3}$ may or may not be caused by combinatorial deposition-induced composition deviations from the $\mathrm{YTaO}_{4}$ stoichiometry. As TBCs are most commonly applied on thermally grown oxides consisting of $\alpha-\mathrm{Al}_{2} \mathrm{O}_{3}$ [42], reactions between $\mathrm{YTaO}_{4}$ and $\alpha-\mathrm{Al}_{2} \mathrm{O}_{3}$ may be critical for applications. Thus, the analysis of the obtained phases with emphasis on their high-temperature behavior should be addressed in future work.

Results of the thermal stability studies are summarized in Figure 2b. As-deposited coatings, including the supersaturated XRD single-phase $t$ coatings, are stable up to at least $825^{\circ} \mathrm{C}$. Upon annealing to $1300{ }^{\circ} \mathrm{C}, \mathrm{M}^{\prime}$ remains stable, and for $28 \mathrm{~mol} \% \mathrm{ZrO}_{2}$ and above, a two-phase region with $M^{\prime}$ and $t$ is observed. After annealing to $1650{ }^{\circ} \mathrm{C}$, the $t$ phase remains unaffected, while $M^{\prime}$ transforms to $M . M^{\prime}$ is reported to transform to the high-temperature $T$ phase at approximately $1450{ }^{\circ} \mathrm{C}$ [15]. Upon cooling, the structurally similar $M$ phase is formed. However, for coatings with 28 to $44 \mathrm{~mol} \% \mathrm{ZrO}_{2}, T$ was partly retained down to room temperature. This behavior is independent of the cooling rate, $40 \mathrm{~K} / \mathrm{min}$ in case of the $1650{ }^{\circ} \mathrm{C}$ annealing procedure compared to an average cooling rate of approximately $4 \mathrm{~K} / \mathrm{min}$ for in situ heating XRD studies. $\mathrm{Zr}$ is known to promote the high-temperature tetragonal structure of $\mathrm{YTaO}_{4}$, as shown by reduced $M-T$ transformation temperatures [21]. Previously, Gurak et al. [21], Shian et al. [8], as well as van Sluytman et al. [27] were able to retain fractions of $T$ at room temperature for $\mathrm{Zr}$ containing $\mathrm{YTaO}_{4}$ after annealing. Along with the stabilization of $T$ to room temperature, the $M$ to $T$ transformation temperature was significantly lowered. Reduced $M$-phase peak intensities along with increasing $T$ phase peak intensities were observable after initial heating to $80^{\circ} \mathrm{C}$, which is well below the previously reported temperature range of $250{ }^{\circ} \mathrm{C}$ to $450 \pm 20^{\circ} \mathrm{C}$ [21] for the same compositional range. On the other hand, the $M^{\prime}$ to $T$ transformation temperature was observed to be in between 1300 and $1650{ }^{\circ} \mathrm{C}$ for all analyzed $\mathrm{ZrO}_{2}$ contents, which is in excellent agreement with observations by Flamant et al. [15] reporting the $M^{\prime}$ to $T$ transformation temperature to be independent of $\mathrm{ZrO}_{2}$ at approximately $1450{ }^{\circ} \mathrm{C}$.

$M^{\prime}$ as well as $M$ coatings without $t$ solid solution were obtained for 0 to $15 \mathrm{~mol} \%$ $\mathrm{ZrO}_{2}$ after annealing to 1300 and $1650{ }^{\circ} \mathrm{C}$, respectively. Hence, similar solubility limits of $\mathrm{ZrO}_{2}$ in $M$ and $M^{\prime}$ in between 15 and $28 \mathrm{~mol} \%$ are derived. These are in good agreement with the solubility limits of $M^{\prime}$ and $M$ to be in the range of $25-28 \mathrm{~mol} \% \mathrm{ZrO}_{2}$ found in literature $[15,21]$. However, due to the here observed Al containing impurity phases, an unambiguous statement on the solubility limit of $M$ and $M^{\prime}$ is not feasible.

Grain sizes of as-deposited as well as samples annealed at 1300 and $1650{ }^{\circ} \mathrm{C}$ are decreasing with increasing $\mathrm{ZrO}_{2}$ content, as can be seen in the top-view SEM images depicted in Figure 9. This is in line with observations on sintered samples by Shian et al. [8]. All single-phase $M$ coatings annealed at $1650{ }^{\circ} \mathrm{C}$ exhibit grains covering several tenths of $\mu \mathrm{m}$ of the substrate, while leaving other substrate regions uncovered. Coatings annealed at $1650{ }^{\circ} \mathrm{C}$ with $\mathrm{ZrO}_{2}$ contents of $28 \mathrm{~mol} \%$ or higher exhibit reduced grain sizes and no 
dewetting of the substrate. The formation of $t$ as a second phase may inhibit grain growth The correlations of grain sizes with $\mathrm{ZrO}_{2}$ contents are also observed in cross-sectional STEM imaging (Figure $5 \mathrm{~h}-\mathrm{j}$ ). Furthermore, the large variation in grain sizes results in significant differences in roughness. The arithmetical mean roughness $R_{a}$ range for $\mathrm{ZrO}_{2}$ free samples is from $10 \pm 2 \mathrm{~nm}$ to $739 \pm 87 \mathrm{~nm}$ and for $44 \mathrm{~mol} \% \mathrm{ZrO}_{2}$, it is from $14 \pm 3 \mathrm{~nm}$ to $172 \pm 14 \mathrm{~nm}$ for the as-deposited and $1650{ }^{\circ} \mathrm{C}$ annealed state, respectively.

For all coatings annealed at $1650^{\circ} \mathrm{C}$, twinned grains were observed by top-view SEM (Figure 9) and cross-sectional STEM (Figure 5h,i). Twinning is a known characteristic of a ferroelastic response to stresses [43]. Hence, the here observed twins are expected to be induced by thermal stresses in ferroelastic $M[6,8]$, resulting in (ferroelastic) toughening of $M$-containing samples. For increased $\mathrm{ZrO}_{2}$ concentrations, a reduction of the twin population is observed, which correlates with the observation of lower $M$ and higher $T$ phase fractions at room temperature. No twinning and hence no toughening is observed for samples annealed at $1300{ }^{\circ} \mathrm{C}$. Consequently, cracks of various sizes evolved in all of these samples (Figure 9), although these $M^{\prime}$-containing samples were exposed to a $350{ }^{\circ} \mathrm{C}$ lower annealing temperature and thus are expected to exhibit significantly smaller thermal strains compared to coatings exhibiting $M$. Crack formation may also be enabled by the presence of pores along grain boundaries as observed in cross-sectional STEM images for all analyzed samples annealed at $1300^{\circ} \mathrm{C}$ (Figure $5 \mathrm{c}-\mathrm{e}$ ). Hence, the results indicate a superior behavior of the $M$ phase as a TBC compared to $M^{\prime}$ coatings.

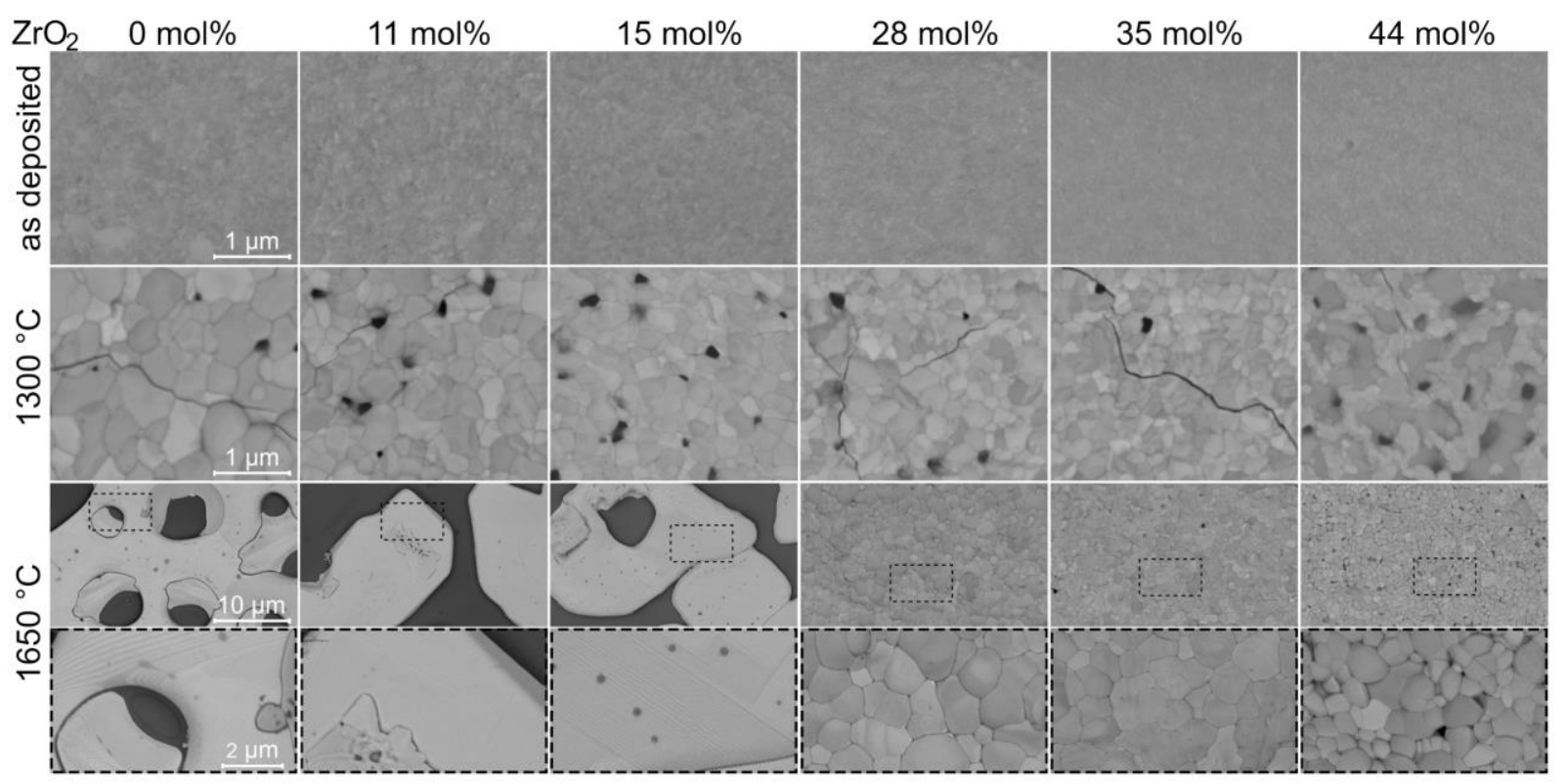

Figure 9. Top view of $\mathrm{Y}_{(1-\mathrm{x}) / 2} \mathrm{Ta}_{(1-\mathrm{x}) / 2} \mathrm{Zr}_{\mathrm{x}} \mathrm{O}_{2}$ coatings by SEM with 0 to $44 \mathrm{~mol} \% \mathrm{ZrO}_{2}$ in as-deposited, annealed for $1 \mathrm{~h}$ at $1300{ }^{\circ} \mathrm{C}$, and annealed for $1 \mathrm{~h}$ at $1650^{\circ} \mathrm{C}$ conditions. For samples annealed at $1650{ }^{\circ} \mathrm{C}$, two magnifications are shown.

\subsection{Elastic Properties of As-Deposited Coatings}

The elastic modulus was assessed by nanoindentation. Resulting elastic moduli in dependence of $\mathrm{ZrO}_{2}$ are depicted in Figure 10. As-deposited $\mathrm{ZrO}_{2}$ free $M^{\prime}$ coatings yielded an elastic modulus of $182 \pm 21 \mathrm{GPa}$, with the error given as the standard deviation of all measured moduli. Reported results of ab initio calculations of the elastic modulus of $M^{\prime}$ vary considerably. While $\mathrm{Wu}$ et al. [44] obtained a value of $147 \mathrm{GPa}$, Zhang et al. [14] calculated the elastic modulus to be $170.2 \mathrm{GPa}$. Hence, the measured elastic modulus of the as-deposited coatings is significantly higher than the calculated value by $\mathrm{Wu}$ et al. but agrees within the error of the measurement with ab initio results by Zhang et al. Wu et al. also reported an experimentally derived elastic modulus of $100 \mathrm{GPa}$ determined by nanoindentation for spark plasma sintered $M^{\prime}$ [44]. The higher elastic moduli in this 
work may be rationalized by a higher density of the samples and by compressive stresses common for PVD-deposited coatings [45]. Additions of $\mathrm{ZrO}_{2}$ did not show a significant impact on the measured elastic moduli. Due to the increase in roughness after annealing, no reliable nanoindentation measurements were feasible.

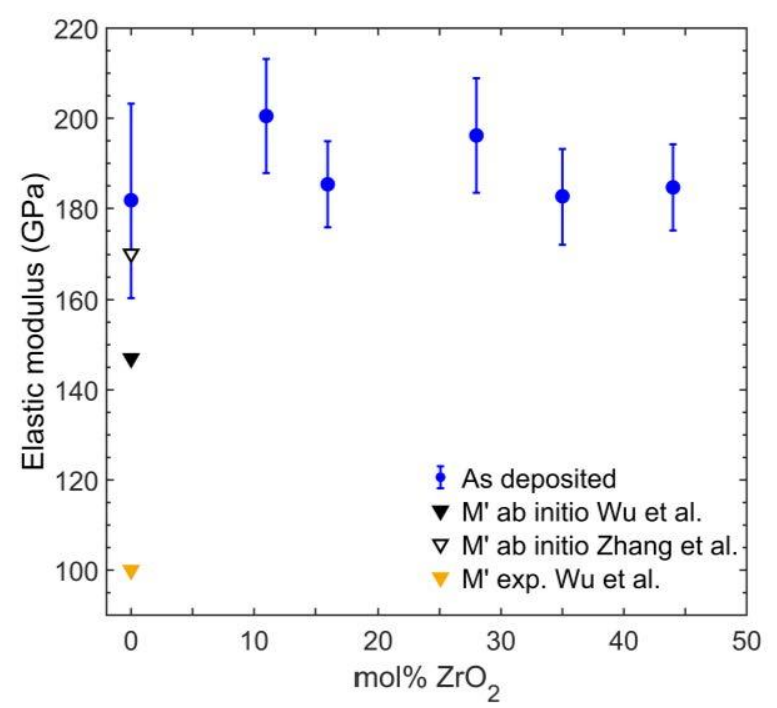

Figure 10. Elastic modulus measured by nanoindentation as a function of $\mathrm{ZrO}_{2}$ content for asdeposited coatings (blue). Black symbols indicate ab initio calculated elastic moduli by Wu et al. (filled symbol) [44] and Zhang et al. (open symbol) [14] for $\mathrm{M}^{\prime}$. Experimental results by Wu et al. [44] are shown in orange.

\section{Conclusions}

$\mathrm{Y}_{(1-\mathrm{x}) / 2} \mathrm{Ta}_{(1-\mathrm{x}) / 2} \mathrm{Zr}_{\mathrm{x}} \mathrm{O}_{2}$ coatings with $\mathrm{ZrO}_{2}$ contents ranging from 0 to $44 \mathrm{~mol} \%$ were synthesized by reactive DCMS. For $\mathrm{ZrO}_{2}$ free $\mathrm{YTaO}_{4}$, a substrate temperature of $900{ }^{\circ} \mathrm{C}$ resulted in the formation of XRD phase-pure $M^{\prime}$ coatings. The addition of 11 to $15 \mathrm{~mol} \%$ $\mathrm{ZrO}_{2}$ led to the formation of tetragonal $t-\mathrm{Zr}(\mathrm{Y}, \mathrm{Ta}) \mathrm{O}_{2}$ next to $M^{\prime}$. XRD phase-pure $t$ coatings were deposited for unprecedentedly low $\mathrm{ZrO}_{2}$ contents of 44 and down to $28 \mathrm{~mol} \%$. The formation of the metastable tetragonal structure may be mediated by small crystallite sizes in the range of $20 \mathrm{~nm}$ and/or kinetic limitations during growth.

Whereas $M^{\prime}$ remained stable after annealing at $1300^{\circ} \mathrm{C}$ for $1 \mathrm{~h}, M$ was formed after annealing at $1650^{\circ} \mathrm{C}$. XRD phase analysis after annealing revealed solubility limits of $\mathrm{ZrO}_{2}$ in $M^{\prime}$ as well as $M$ in-between 15 and $28 \mathrm{~mol} \%$, whereas as-deposited coatings including metastable phases exhibit a solubility limit of $\mathrm{ZrO}_{2}$ in $M^{\prime}<15 \mathrm{~mol} \%$. As deposited phasepure $t$ samples obtained for $\mathrm{ZrO}_{2} \geq 28 \mathrm{~mol} \%$ transformed to $M^{\prime}+t$ and $M+t$ phase regions after annealing to 1300 and $1650{ }^{\circ} \mathrm{C}$, respectively. Furthermore, for these compositions, $T$ was observed at room temperature after annealing to $1650{ }^{\circ} \mathrm{C}$. This $T$ phase fraction increased in in situ heating XRD experiments at temperatures as low as $80^{\circ} \mathrm{C}$, with the transition of $M$ phase into $T$ completed at $480^{\circ} \mathrm{C}$.

Crack formation was observed by SEM imaging for all coatings after annealing at $1300{ }^{\circ} \mathrm{C}$. It may be speculated that this is induced by the thermal expansion mismatches between the $\alpha-\mathrm{Al}_{2} \mathrm{O}_{3}$ substrate and the $\mathrm{M}^{\prime}$ coatings. Coatings annealed at $1650{ }^{\circ} \mathrm{C}$, containing $M$-phase, showed twinning but no crack formation, which may be rationalized by the ferroelastic behavior of $M$. For $\leq 15 \mathrm{~mol} \% \mathrm{ZrO}_{2}$, annealing to $1650{ }^{\circ} \mathrm{C}$ led to partial dewetting of the substrate. Furthermore, heat treatment at $1650{ }^{\circ} \mathrm{C}$ gave rise to a reaction of the deposited coating with the $\alpha-\mathrm{Al}_{2} \mathrm{O}_{3}$ substrate independent of $\mathrm{ZrO}_{2}$ contents. This resulted in the formation of orthorhombic $\mathrm{AlTaO}_{4}$ and a yet unknown Ta-Y-Al-O compound. Hence, the here presented results motivate further analysis of the interaction of $M-\mathrm{YTa}(\mathrm{Zr}) \mathrm{O}_{4}$ solid solutions and $\alpha-\mathrm{Al}_{2} \mathrm{O}_{3}$ to assess the suitability of $\mathrm{YTaO}_{4}$ as $\mathrm{TBC}$ on aluminides. 
Author Contributions: B.S., K.G.P. and J.M.S. conceived the research. B.S. and K.G.P. deposited the coatings. D.M.H. annealed the samples. S.R. and J.M. provided WDX measurements. B.S. and K.G.P. performed EDX and ex situ as well as in situ XRD experiments. SEM and STEM imaging as well as nanoindentation was carried out by B.S. APT was conducted by M.H. All authors gave input in the evaluation, discussion, and editing of the individual manuscripts. All authors have read and agreed to the published version of the manuscript.

Funding: J.M.S. gratefully acknowledges financial support from the Max Planck Fellow Program.

Data Availability Statement: The data presented in this study are available on request from the corresponding author.

Conflicts of Interest: The authors declare that they have no known competing financial interests or personal relationships that could have appeared to influence the work reported in this paper.

\section{References}

1. Padture, N.P.; Gell, M.; Jordan, E.H. Materials science-Thermal barrier coatings for gas-turbine engine applications. Science 2002, 296, 280-284. [CrossRef]

2. Clarke, D.R.; Oechsner, M.; Padture, N.P. Thermal-barrier coatings for more efficient gas-turbine engines. MRS Bull. 2012, 37, 891-898. [CrossRef]

3. Padture, N.P. Advanced structural ceramics in aerospace propulsion. Nat. Mater. 2016, 15, 804-809. [CrossRef] [PubMed]

4. Pitek, F.M.; Levi, C.G. Opportunities for TBCs in the $\mathrm{ZrO}_{2}-\mathrm{YO}_{1.5}-\mathrm{TaO}_{2.5}$ system. Surf. Coat. Technol. 2007, 201, 6044-6050. [CrossRef]

5. Limarga, A.M.; Shian, S.; Leckie, R.M.; Levi, C.G.; Clarke, D.R. Thermal conductivity of single- and multi-phase compositions in the $\mathrm{ZrO}_{2}-\mathrm{Y}_{2} \mathrm{O}_{3}-\mathrm{Ta}_{2} \mathrm{O}_{5}$ system. J. Eur. Ceram. Soc. 2014, 34, 3085-3094. [CrossRef]

6. Feng, J.; Shian, S.; Xiao, B.; Clarke, D.R. First-principles calculations of the high-temperature phase transformation in yttrium tantalate. Phys. Rev. B 2014, 90, 094102. [CrossRef]

7. Zong, R.; Wu, F.; Song, P.; Feng, J. Influence of zirconia alloying on the thermophysical and mechanical properties of $\mathrm{YTaO}_{4}$ ceramics. Ceram. Int. 2019, 45, 24894-24899. [CrossRef]

8. Shian, S.; Sarin, P.; Gurak, M.; Baram, M.; Kriven, W.M.; Clarke, D.R. The tetragonal-monoclinic, ferroelastic transformation in yttrium tantalate and effect of zirconia alloying. Acta Mater. 2014, 69, 196-202. [CrossRef]

9. Yang, W.; Ye, F.; Yan, S.; Guo, L. The corrosion behaviors of thermal barrier material of $\mathrm{M}_{-} \mathrm{YTaO}_{4}$ attacked by $\mathrm{CMAS}$ at $1250{ }^{\circ} \mathrm{C}$. Ceram. Int. 2020, 46, 9311-9318. [CrossRef]

10. Wolten, G.M.; Chase, A.B. Synthetic Fergusonites and a New Polymorph of Yttrium Tantalate. Am. Miner. 1967, 52, 1536-1541.

11. Wolten, G.M. The structure of the $\mathrm{M}^{\prime}$-phase of $\mathrm{YTaO}_{4}$, a third Fergusonite polymorph. Acta Crystallogr. 1967, $23,939-944$. [CrossRef]

12. Mather, S.A.; Davies, P.K. Nonequilibrium Phase-Formation in Oxides Prepared at Low-Temperature-Fergusonite-Related Phases. J. Am. Ceram. Soc. 1995, 78, 2737-2745. [CrossRef]

13. Heinze, S.G.; Natarajan, A.R.; Levi, C.G.; Van der Ven, A. Crystallography and substitution patterns in the $\mathrm{ZrO}_{2}-\mathrm{YTaO}_{4}$ system. Phys. Rev. Mater. 2018, 2, 073607. [CrossRef]

14. Zhang, F.; Zhang, G.; Yang, L.; Zhou, Y.; Du, Y. Thermodynamic modeling of $\mathrm{YO}_{1.5}-\mathrm{TaO}_{2.5}$ system and the effects of elastic strain energy and diffusion on phase transformation of $\mathrm{YTaO}_{4}$. J. Eur. Ceram. Soc. 2019, 39, 5036-5047. [CrossRef]

15. Flamant, Q.; Gurak, M.; Clarke, D.R. The effect of zirconia substitution on the high-temperature transformation of the monoclinicprime phase in yttrium tantalate. J. Eur. Ceram. Soc. 2018, 38, 3925-3931. [CrossRef]

16. Yokogawa, Y.; Yoshimura, M. High-Temperature Phase-Relations in the System $\mathrm{Y}_{2} \mathrm{O}_{3}-\mathrm{Ta}_{2} \mathrm{O}_{5}$. J. Am. Ceram. Soc. 1991, 74, 2077-2081. [CrossRef]

17. Ryumin, M.A.; Sazonov, E.G.; Guskov, V.N.; Nikiforova, G.E.; Gagarin, P.G.; Guskov, A.V.; Gavrichev, K.S.; Baldaev, L.K.; Mazilin, I.V.; Golushina, L.N. Low-Temperature heat capacity of yttrium orthotantalate. Inorg. Mater. 2016, 52, 1149-1154. [CrossRef]

18. Wang, J.; Zhou, Y.; Chong, X.; Zhou, R.; Feng, J. Microstructure and thermal properties of a promising thermal barrier coating: $\mathrm{YTaO}_{4}$. Ceram. Int. 2016, 42, 13876-13881. [CrossRef]

19. Brixner, L.H.; Chen, H.Y. On the Structural and Luminescent Properties of the $\mathrm{M}^{\prime} \mathrm{LnTaO}_{4}$ Rare Earth Tantalates. J. Electrochem. Soc. 1983, 130, 2435-2443.

20. Yildirim, S.; Demirci, S.; Ertekin, K.; Celik, E.; Alicikus, Z.A. Production, characterization, and luminescent properties of Eu ${ }^{3+}$ doped yttrium niobate-tantalate films. J. Adv. Ceram. 2017, 6, 33-42. [CrossRef]

21. Gurak, M.; Flamant, Q.; Laversenne, L.; Clarke, D.R. On the Yttrium Tantalate-Zirconia phase diagram. J. Eur. Ceram. Soc. 2018, 38, 3317-3324. [CrossRef]

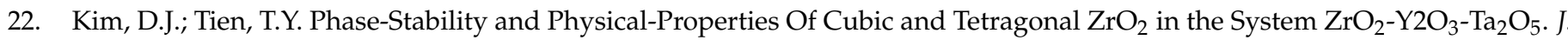
Am. Ceram. Soc. 1991, 74, 3061-3065. [CrossRef] 
23. Shukla, S.; Seal, S. Mechanisms of room temperature metastable tetragonal phase stabilisation in zirconia. Int. Mater. Rev. 2005, 50, 45-64. [CrossRef]

24. Macauley, C.A.; Fernandez, A.N.; Van Sluytman, J.S.; Levi, C.G. Phase equilibria in the $\mathrm{ZrO}_{2}-\mathrm{YO}_{1.5}-\mathrm{TaO}_{2.5}$ system at $1250{ }^{\circ} \mathrm{C} . J$. Eur. Ceram. Soc. 2018, 38, 4523-4532. [CrossRef]

25. Macauley, C.A.; Fernandez, A.N.; Levi, C.G. Phase equilibria in the $\mathrm{ZrO}_{2}-\mathrm{YO}_{1.5}-\mathrm{TaO}_{2.5}$ system at $1500{ }^{\circ} \mathrm{C}$. J. Eur. Ceram. Soc. 2017, 37, 4888-4901. [CrossRef]

26. Fernandez, A.N.; Macauley, C.A.; Park, D.; Levi, C.G. Sub-solidus phase equilibria in the $\mathrm{YO}_{1.5}-\mathrm{TaO}_{2.5}$ system. J. Eur. Ceram. Soc. 2018, 38, 4786-4798. [CrossRef]

27. Van Sluytman, J.S.; Krämer, S.; Tolpygo, V.K.; Levi, C.G. Microstructure evolution of $\mathrm{ZrO}_{2}-\mathrm{YbTaO}_{4}$ thermal barrier coatings. Acta Mater. 2015, 96, 133-142. [CrossRef]

28. Heinze, S.G.; Van Sluytman, J.S.; Levi, C.G. Microstructure evolution and physical properties of $\mathrm{ZrO}_{2}-(\mathrm{Y}+\mathrm{Yb}) \mathrm{O}_{1.5}-\mathrm{TaO}_{2.5}$ thermal barrier coatings. Surf. Coat. Technol. 2020, 389, 125648. [CrossRef]

29. Thompson, K.; Lawrence, D.; Larson, D.J.; Olson, J.D.; Kelly, T.F.; Gorman, B. In situ site-specific specimen preparation for atom probe tomography. Ultramicroscopy 2007, 107, 131-139. [CrossRef]

30. Oliver, W.C.; Pharr, G.M. An Improved Technique for Determining Hardness and Elastic-Modulus Using Load and Displacement Sensing Indentation Experiments. J. Mater. Res. 1992, 7, 1564-1583. [CrossRef]

31. Bolvardi, H.; Emmerlich, J.; Mráz, S.; Arndt, M.; Rudigier, H.; Schneider, J.M. Low temperature synthesis of $\mathrm{Mo}_{2} \mathrm{BC}$ thin films. Thin Solid Film. 2013, 542, 5-7. [CrossRef]

32. Walter, C.; Sigumonrong, D.P.; El-Raghy, T.; Schneider, J.M. Towards large area deposition of $\mathrm{Cr}_{2} \mathrm{AlC}_{\text {on }}$ steel. Thin Solid Film. 2006, 515, 389-393. [CrossRef]

33. Abdulkadhim, A.; to Baben, M.; Takahashi, T.; Schnabel, V.; Hans, M.; Polzer, C.; Polcik, P.; Schneider, J.M. Crystallization kinetics of amorphous $\mathrm{Cr}_{2} \mathrm{AlC}$ thin films. Surf. Coat. Technol. 2011, 206, 599-603. [CrossRef]

34. Moody, M.P.; Stephenson, L.T.; Ceguerra, A.V.; Ringer, S.P. Quantitative binomial distribution analyses of nanoscale like-solute atom clustering and segregation in atom probe tomography data. Microsc. Res. Tech. 2008, 71, 542-550. [CrossRef]

35. Shannon, R. Revised effective ionic radii and systematic studies of interatomic distances in halides and chalcogenides. Acta Crystallogr. Sect. A 1976, 32, 751-767. [CrossRef]

36. Bhattachaya, A.; Shklover, V.; Kunze, K.; Steurer, W. Effect of $7 \mathrm{YSZ}$ on the long-term stability of $\mathrm{YTaO}_{4}$ doped $\mathrm{ZrO}_{2}$ system. J. Eur. Ceram. Soc. 2011, 31, 2897-2901.

37. McHale, J.M.; Auroux, A.; Perrotta, A.J.; Navrotsky, A. Surface energies and thermodynamic phase stability in nanocrystalline aluminas. Science 1997, 277, 788-791. [CrossRef]

38. Hans, M.; Music, D.; Chen, Y.T.; Patterer, L.; Eriksson, A.O.; Kurapov, D.; Ramm, J.; Arndt, M.; Rudigier, H.; Schneider, J.M. Crystallite size-dependent metastable phase formation of TiAlN coatings. Sci. Rep. 2017, 7, 16096. [CrossRef]

39. Scherrer, P. Bestimmung der Größe und der inneren Struktur von Kolloidteilchen mittels Röntgenstrahlen. Nachr. Ges. Wiss. Gött. Math.-Phys. Kl. 1918, 98-100.

40. Nahif, F.; Music, D.; Mráz, S.; Bolvardi, H.; Conrads, L.; Schneider, J.M. The effect of Si alloying on the thermal stability of $\mathrm{Al}_{2} \mathrm{O}_{3}$ films deposited by filtered cathodic arc. Surf. Coat. Technol. 2013, 235, 250-258. [CrossRef]

41. Thompson, C.V. Solid-State Dewetting of Thin Films. Annu. Rev. Mater. Res. 2012, 42, 399-434. [CrossRef]

42. Clarke, D.R.; Levi, C.G. Materials Design for the Next Generation Thermal Barrier Coatings. Annu. Rev. Mater. Res. 2003, 33, 383-417. [CrossRef]

43. Aizu, K. Possible Species of "Ferroelastic" Crystals and of Simultaneously Ferroelectric and Ferroelastic Crystals. J. Phys. Soc. Japan 1969, 27, 387-396. [CrossRef]

44. Wu, P.; Zhou, Y.; Wu, F.; Hu, M.; Chong, X.; Feng, J. Theoretical and experimental investigations of mechanical properties for polymorphous $\mathrm{YTaO}_{4}$ ceramics. J. Am. Ceram. Soc. 2019, 102, 7656-7664. [CrossRef]

45. Ruess, H.; Music, D.; Bahr, A.; Schneider, J.M. Effect of chemical composition, defect structure, and stress state on the elastic properties of (V1-x Al x )1-y N y. J. Phys. Condens. Matter 2019, 32, 025901. [CrossRef] 